\title{
CORRIGENDUM
}

\section{Transcriptional targeting of adenoviral vector through the CXCR4 tumor-specific promoter}

ZB Zhu, SK Makhija, B Lu, M Wang, L Kaliberova, B Liu, AA Rivera, DM Nettelbeck, PJ Mahasreshti, CA Leath III, M Yamaoto, RD Alvarez and DT Curiel

Gene Therapy (2006) 13, 374. doi:10.1038/sj.gt.3302731

Correction to: Gene Therapy (2004) 11, 645-648. doi:10.1038/sj.gt.3302089

The below author name was published incorrectly (shown above), the correct name is given below.

M Yamamoto

The authors would like to apologise for this mistake. 